\title{
SECONDARY MELT INCLUSIONS IN OLIVINE FROM UNALTERED KIMBERLITES OF THE UDACHNAYA-EASTERN PIPE, YAKUTIA
}

\author{
Alexander V. Golovin, Victor V. Sharygin, Nikolai P. Pokhilenko, Vladimir G. Mal'kovets, \\ Nikolai V. Sobolev \\ Institute of Mineralogy and Petrography, UIGGM SD RAS, Novosibirsk, Russia
}

\section{INTRODUCTION}

In the central part of the Udachnaya-Eastern kimberlite pipe situated in the Daldyn-Alakit field of the Yakutian kimberlite province, unique (in high degree of its preservation) kimberlitic rock with abundant olivine, which did not undergo serpentinization, was found at a depth of 350-650 m. This kimberlite can be considered as a primary rock that retained all features of the deepseated melt (Marshintsev et al., 1976). The chemical composition of this kimberlite is as follows (wt \%): $\mathrm{SiO}_{2} 29.8, \mathrm{TiO}_{2} 1.55, \mathrm{Al}_{2} \mathrm{O}_{3} 2.45, \mathrm{FeO}_{\text {tot }} 8.50, \mathrm{MnO}$ $0.16, \mathrm{MgO} 32.0, \mathrm{CaO} 10.8, \mathrm{Na}_{2} \mathrm{O} 0.30, \mathrm{~K}_{2} \mathrm{O} 0.8 ; \mathrm{P}_{2} \mathrm{O}_{5}$ $0.40, \mathrm{CO}_{2} 6.90$, total 93.66. The comparison of this composition with data for various Yakutian kimberlites, including diamond-rich rocks from the Udachnaya and Mir pipes (Sobolev et al., 1986) confirms the unique character of the unaltered kimberlite.

\section{PETROGRAPHY OF ROCK STUDIED}

The rock is brecciated and contains olivine phenocrysts of two generations (olivine-1, 1.0--2.5 mm in size, and olivine-2, $<0.5 \mathrm{~mm}$ ) and rare phlogopite phenocrysts (Marshintsev et al., 1976). Marginal zones of olivine-2 and grains of olivine- 2 contain crystallites of Cr-spinel, orthopyroxene, rutile, phlogopite, and perovskite; ore minerals often decorate growth zones in olivine. Crystallites of $\mathrm{Cr}$-spinel, magnetite, and perovskite are also typical as inclusions in phlogopite phenocrysts. The microgranular groundmass consists of calcite, phlogopite, perovskite, ore minerals (Cr-spinel, Timagnetite, and ilmenite), Na-Ca-carbonates, and sulfides.

\section{PETROGRAPHY OF INCLUSIONS}

Secondary melt inclusions are clustered as linear trails or patches confined to the fractures in olivine- 1 and olivine-2. The inclusions are rounded, droplike, irregular, or semifaceted in shape. Their size ranges from 2 to $80 \mu \mathrm{m}$. The phase composition is as follows: finely crystallized aggregate (carbonates + sulfates + chlorides $)+$ gas \pm transparent crystalline phases \pm ore phases (Fig. 1). Silicates (tetraferriphlogopite, olivine, humite-clinohumite, and diopside), carbonates (calcite, dolomite, siderite, and $\mathrm{Na}$-Ca-carbonates), $\mathrm{Na}$ and $\mathrm{K}$ chlorides, and sulfates have been identified among transparent phases. Magnetite, djerfisherite, and $\mathrm{Ni}-$ pyrrhotite occur as ore phases (magnetite and sulfides are often intergrown). Inclusions with a variable phase composition are observed within one chain.

As was established from the cryometry, the fluid phase of inclusions is composed of a low-density carbon dioxide (triple point lies at -57.0 to $-57.5^{\circ} \mathrm{C}$ ). Thermometric experiments revealed that the inclusions completely homogenize in the range of $700-800^{\circ} \mathrm{C}$. Our thermometric data are generally consistent with previous results on the secondary melt inclusions in olivine from kimberlites of the Udachnaya pipe (Pokhilenko, Usova, 1978; Popivnyak, Laz'ko, 1979; Sobolev et al., 1989).

\section{CHEMISTRY OF INCLUSIONS}

The chemical composition of inclusions was determined on a CAMEBAX microprobe at the United Institute of Geology, Geophysics, and Mineraloggy, Siberian Division, Russian Academy of Sciences using the standard technique. Unfortunately, we failed to obtain reliable results on the composition of heated inclusions, because the homogeneous melt did not quench into glass and formed a fine crystalline aggregate that was partly disintegrated during opening. Nevertheless, higher $\mathrm{Ca}, \mathrm{Na}, \mathrm{K}$, and volatile contents are recorded in the heated inclusions relative to the bulk kimberlite composition. Probably, high alkali and volatile contents in the melt render the formation of homogeneous glass impossible (Mazurin et al., 19731981). The composition of crystalline phase turned out to be most interesting.

Silicates. Tetraferriphlogopite with a variable $\mathrm{Al}_{2} \mathrm{O}_{3}$ content $(0.2-6.5$ wt \%) is the most abundant silicate. The almost Al-free tetraferriphlogopite is predominant (Table 1). The mineral of this composition forms individual grains, $2-10 \mu \mathrm{m}$ in size, and occasionally occurs as rims around $\mathrm{Al}_{2} \mathrm{O}_{3}$-containing 

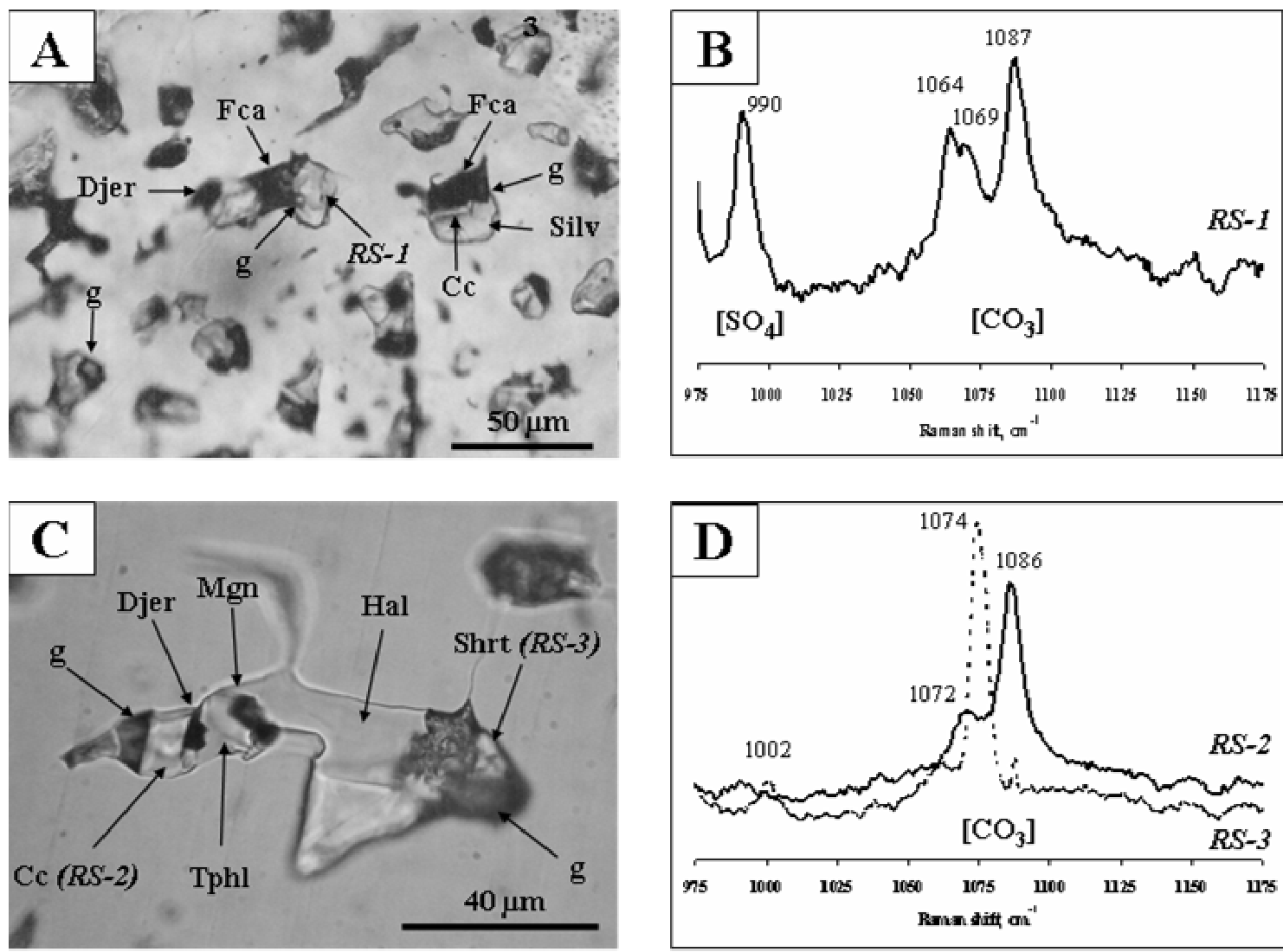

Figure 1. Olivine-hosted secondary inclusions in unaltered kimberlite of the Udachnaya-Eastern pipe (A, C) and Raman spectra of some daughter phases in inclusions (B, D).

Symbols: Hal - halite, Sylv - sylvite, Cc - calcite, Shrt - Na-Ca-carbonate (shortite or zemkorite), Mgn - magnetite, Djer djerfisherite, Tphl - tetraferriphlogopite, Fca - fine-crystalline aggregate; g - gas; $R \boldsymbol{S}$-1-3 - Raman spectra.

tetraferriphlogopite. All micas from melt inclusions differ in phlogopite from the kimberlite groundmass and crystalline inclusions in olivine. The coherent enrichment of phlogopite of groundmass and especially olivine-hosted inclusions in $\mathrm{TiO}_{2}$ and $\mathrm{Cr}_{2} \mathrm{O}_{3}$ (Table 1) indicates that they were crystallized as minerals of the lherzolite assemblage. This is supported by analogy with primary phlogopite inclusions in diamond (Sobolev, Yefimova, 1997). Rare olivine, diopside, and humite-clinohumite are also found in the inclusions (Table 1). Olivine from the inclusions corresponds to $\mathrm{Fo}_{97.0-94.7} \mathrm{Fa}_{2.6-5.0} \mathrm{La}_{0.4}$ in composition and substantially differs in this respect from the host olivine.

Some transparent crystalline phases from unheated inclusions were partly disintegrated during opening, and the Raman spectroscopy was used to obtain more reliable results. The presence of carbonates and sulfates, identified in non-opened inclusions based on characteristic peaks in the region of anion group oscillations was subsequently confirmed by microprobe results.
Carbonates. The melt inclusions contain the following carbonate phases: calcite, dolomite, carbonate of the magnesite-siderite isomorphic series, and $\mathrm{Na}-\mathrm{Ca}-$ carbonates (Table 2). Calcite is practically homogeneous with insignificant variations in $\mathrm{CaO}$ (54$57 \mathrm{wt} \%$ ) and $\mathrm{SrO}(0.2-1.5 \mathrm{wt} \%$ ) contents; $\mathrm{MgO}$ (up to 3.7 wt \%) and $\mathrm{FeO}$ (up to 5.9 wt \%) admixtures were recorded in particular grains. The high $\mathrm{Na}_{2} \mathrm{O}$ content (up to $13 \mathrm{wt} \%$ ) in some crystalline phases from the inclusions indicates that they are probably composed of shortite or zemkorite (Khomyakov et al., 1980; Egorov et al., 1980). Raman peaks in the $1060-1075 \mathrm{~cm}^{-1}$ region allow us to suggest that several $\mathrm{Na}-\mathrm{Ca}$-carbonate phases exist in the inclusions (Fig. 1).

Chlorides, sulfates, and phosphate. The determination of sulfates and chlorides from the melt inclusions turned out to be a complex task, because they are small and hygroscopic. Nevertheless, we succeeded in analyzing some inclusions containing abundant salt phases. Halite and sylvite, often closely intergrown with each other, were reliably identified. In addition the 
Table 1: Chemical composition (wt \%) of daughter silicate phases in olivine-hosted secondary melt inclusions from the Udachnaya-Eastern pipe kimberlites

\begin{tabular}{lllllllllll} 
& $\mathbf{1}$ & $\mathbf{2}$ & $\mathbf{3}$ & $\mathbf{4}$ & $\mathbf{5}$ & $\mathbf{6}$ & $\mathbf{7}$ & $\mathbf{8}$ & $\mathbf{9}$ & $\mathbf{1 0}$ \\
\hline $\boldsymbol{n}$ & 4 & 2 & 2 & 2 & 4 & 3 & 3 & 2 & 1 & 3 \\
$\mathrm{SiO}_{2}$ & 41,31 & 40,57 & 40,47 & 40,43 & 40,24 & 40,39 & 41,13 & 37,43 & 37,99 & 55,48 \\
$\mathrm{TiO}_{2}$ & 0,59 & 2,42 & 0,20 & 0,07 & 0,06 & 0,04 & n.d. & 0,10 & 0,93 & n.d. \\
$\mathrm{Cr}_{2} \mathbf{O}_{3}$ & 0,19 & 1,43 & n.d. & n.d. & n.d. & n.d. & n.d. & n.d. & n.d. & n.d. \\
$\mathbf{A l}_{2} \mathbf{O}_{3}$ & 12,14 & 13,04 & 6,52 & 0,23 & 0,09 & 0,15 & n.d. & n.d. & n.d. & n.d. \\
$\mathbf{F e O}$ & 5,17 & 4,96 & 12,05 & 12,41 & 16,71 & 17,20 & 7,05 & 1,88 & 2,33 & 1,94 \\
$\mathbf{M n O}$ & 0,05 & 0,07 & n.a. & n.a. & n.a. & n.a. & 0,09 & n.d. & n.a. & 0,03 \\
$\mathbf{M g O}$ & 25,38 & 23,64 & 25,08 & 27,45 & 26,60 & 26,44 & 51,14 & 57,40 & 56,05 & 17,40 \\
$\mathbf{N i O}$ & n.a. & n.a. & n.a. & n.a. & n.a. & n.a. & 0,35 & n.a. & n.a. & n.a. \\
$\mathbf{C a O}$ & 0,04 & n.d. & 0,03 & 0,04 & n.d. & n.d. & 0,05 & 0,12 & n.d. & 25,03 \\
$\mathbf{B a O}$ & 0,06 & 0,11 & n.d. & n.d. & n.d. & n.d. & n.d. & n.d. & n.d. & n.d. \\
$\mathbf{N a} \mathbf{O}_{\mathbf{O}} \mathbf{O}$ & 0,10 & 0,06 & 0,12 & 0,23 & 0,13 & 0,16 & n.d. & n.d. & n.d. & 0,33 \\
$\mathbf{K} \mathbf{O}$ & 10,26 & 10,26 & 10,12 & 10,36 & 10,24 & 10,15 & n.d. & n.d. & n.d. & n.d. \\
$\mathbf{F}$ & 0,42 & 0,50 & 0,15 & 0,44 & 0,44 & 0,16 & n.a. & 3,39 & 2,50 & n.a. \\
$\mathbf{C l}$ & 0,06 & 0,07 & n.d. & n.d. & n.d. & n.d. & n.d. & n.d. & n.a. & n.d. \\
$\mathbf{T o t a l}$ & 95,75 & 97,12 & 94,73 & 91,65 & 94,50 & 94,69 & 99,81 & 100,32 & 99,80 & 100,22 \\
$\mathbf{O}=\mathbf{F}_{2}$ & 0,18 & 0,21 & 0,06 & 0,19 & 0,19 & 0,07 & 0,00 & 1,43 & 1,05 & 0,00 \\
$\mathbf{T o t a l}$ & 95,58 & 96,91 & 94,67 & 91,47 & 94,31 & 94,62 & 99,81 & 98,89 & 98,74 & 100,22
\end{tabular}

1 - phlogopite in groundmass; 2 - phlogopite inclusion in olivine; 3-6 - tetraferriphlogopite in olivine-hosted melt inclusions: 3-4 - core and margin of one crystal, 5-6 - separate grains; 7 - host olivine; 8-9 - humite-clinohumite in inclusions; 10 - diopside in inclusions. $\mathbf{n}$ means numbers of analyses, n.d. - not detected; n.a. - not analyzed. Detection limit is $0.11 \mathrm{wt} \%$ for $\mathrm{F}$ and $0.02 \mathrm{wt} \%$ for $\mathrm{Cl}$.

Table 2: Chemical composition (wt \%) of carbonates, sulfate, and phosphate in olivinehosted secondary melt inclusions from the Udachnaya-Eastern pipe kimberlites

\begin{tabular}{lllllllll} 
& $\mathbf{1}$ & $\mathbf{2}$ & $\mathbf{3}$ & $\mathbf{4}$ & $\mathbf{5}$ & $\mathbf{6}$ & $\mathbf{7}$ & $\mathbf{8}$ \\
\hline $\boldsymbol{n}$ & 1 & 1 & 1 & 2 & 2 & 1 & 2 & 2 \\
$\mathbf{S i O}_{2}$ & n.d. & n.d. & n.d. & n.d. & n.d. & n.d. & n.d. & 0,43 \\
$\mathbf{F e O}$ & 0,53 & 0,30 & 0,18 & 25,66 & 1,68 & 0,63 & 0,63 & 4,27 \\
$\mathbf{M g O}$ & 0,21 & 0,19 & 0,21 & 40,79 & 23,34 & 0,54 & 0,06 & 45,94 \\
$\mathbf{C a O}$ & 57,19 & 54,26 & 54,03 & 0,00 & 29,20 & 43,41 & 0,13 & 1,05 \\
$\mathbf{B a O}$ & n.d. & n.d. & n.d. & 0,10 & n.d. & n.d. & 0,09 & n.d. \\
$\mathbf{S r O}$ & 0,58 & 1,22 & 1,54 & n.d. & 0,42 & 1,01 & n.a. & 0,22 \\
$\mathbf{N a}_{2} \mathbf{O}$ & n.d. & 0,24 & 0,31 & n.d. & 0,06 & 11,08 & 19,03 & 2,48 \\
$\mathbf{K}_{\mathbf{2}} \mathbf{O}$ & n.d. & n.d. & n.d. & n.d. & n.d. & 4,87 & 29,08 & 0,16 \\
$\mathbf{P}_{\mathbf{2}} \mathbf{O}_{5}$ & n.d. & n.d. & n.d. & n.d. & n.d. & n.d. & n.a. & 45,30 \\
$\mathbf{S O}_{3}$ & n.d. & n.d. & n.d. & n.d. & n.d. & 1,61 & 50,50 & n.d. \\
Total & 58,52 & 56,22 & 56,27 & 66,55 & 54,70 & 63,15 & 99,52 & 99,85
\end{tabular}

1-3 - calcite; 4 - carbonate of the magnesite-siderite series; 5 - dolomite; 6 - Na-Ca-carbonate (shortite ?, the trapping of calcite is possible during microprobe analysis); 7 - aphthitalite; 8 - Mg-phosphate. 
Table 3: Chemical composition (wt \%) of some chlorides from olivine-hosted inclusions

\begin{tabular}{lllll} 
& $\mathbf{1}$ & $\mathbf{2}$ & $\mathbf{3}$ & $\mathbf{4}$ \\
\hline $\mathbf{M g}$ & 0,00 & 0,00 & 4,11 & 15,60 \\
$\mathbf{K}$ & 5,56 & 48,20 & 4,72 & 0,00 \\
$\mathbf{N a}$ & 33,86 & 3,95 & 25,48 & 26,32 \\
$\mathbf{C l}$ & 60,48 & 47,55 & 65,19 & 14,12 \\
Total & 99,90 & 99,70 & 99,50 & 56,04
\end{tabular}

1 - halite + silvite; 2 - sylvite + halite; 3 - halite + silvite + chloromagnesite; 4 - Na-Mg-chloride.

inclusions probably contain chloromagnesite $\mathrm{MgCl}_{2}$ and an unidentified $\mathrm{Na}-\mathrm{Mg}$-chloride $\mathrm{Mg} 15.6 \mathrm{wt} \%$, Na $26.3 \mathrm{wt} \%$, and $\mathrm{Cl} 14.1 \mathrm{wt} \%$, Table 3). Identification of sulfates was most difficult. According to the Raman spectra of $\left[\mathrm{SO}_{4}\right]$ groups in the $980-1010 \mathrm{~cm}^{-1}$ region (Fig. 1), the occurrence of thenardite, glauberite, and aphthitalite, as well as barite and celestite, is most probable. However, microprobe results yielded no more than 3 wt \% $\mathrm{SO}_{3}$ in most inclusions, and $\mathrm{Ba}$ and $\mathrm{Sr}$ were not detected. Aphthitalite with the $\mathrm{K}_{2} \mathrm{Na}_{2}\left(\mathrm{SO}_{4}\right)_{2}$ composition was detected in only one inclusion. The Mg-phosphate was identified in some inclusions in association with Ca-carbonates (Table 2).

Oxides. Magnetite reveals insignificant variations in $\mathrm{MgO}$ (2.6-5.6 wt \%) and $\mathrm{FeO}$ (85-89 wt \%). The mineral belongs to the $\mathrm{MgFe}_{2} \mathrm{O}_{4}-\mathrm{FeFe}_{2} \mathrm{O}_{4}$ series with $<1$ mole $\%$ of other end members.

Sulfides. Djerfisherite from the inclusions is characterized by a wide compositional range (in wt \%): Fe 32.6-38.5, Ni 4.2-23.1, Co 0.1-0.5, Cu 0-17.6, K 8.99.1, $\mathrm{Na}$ up to 0.7, $\mathrm{S}$ 32.7-33.4, and $\mathrm{Cl}$ 1.2-1.4. Variations within a particular grain from the center to margin are insignificant. In addition to djerfisherite, $\mathrm{Ni}$ pyrrhotite (Fe 55.1 wt $\%$, Ni 4.4. wt \%, Co 0.4 wt \%, $\mathrm{Cu} 0.8$ wt \%, and S 38.9 wt \%) was identified in one case. Djerfisherite was previously found in kimberlites as rims around sulfide segregations in diamonds and xenoliths and as a late magmatic phase in the groundmass (Dobrovol'skaya et al., 1975; Clarke et al., 1977; 1994; Bulanova et al., 1990; Zedgenizov et al., 1998).

\section{DISCUSSION}

The highest possible pressure of inclusion trapping calculated with a FLINCOR program is $<1 \mathrm{kbar}$ at $800^{\circ} \mathrm{C}$. Hence, the inclusions were trapped at shallow depth conditions and likely are relicts of the highly evolved kimberlitic melt. Judging from the assemblage of crystalline phases in the melt inclusions, the kimberlitic melt presumably had a silicate-carbonate composition with high volatile $(\mathrm{Cl}, \mathrm{S})$ contents at the late stage of crystallization. Thus, the evolution of kimberlitic melt during crystallization was directed toward the enrichment in $\mathrm{CaO}, \mathrm{Na}_{2} \mathrm{O}, \mathrm{K}_{2} \mathrm{O}, \mathrm{FeO}$, and volatile components and the depletion in $\mathrm{SiO}_{2}, \mathrm{MgO}$, and $\mathrm{Al}_{2} \mathrm{O}_{3}$. After the crystallization of olivine-2, the melt acquired silicate-carbonate composition with a marked carbonatitic trend. The further crystallization of minerals in the groundmass (phlogopite, Ti-magnetite, and perovskite) gave rise to the formation of alkalinecarbonatitic residual melt. At the same time, $\mathrm{Ca}, \mathrm{K}$, $\mathrm{CO}_{2}$, and incompatible elements $(\mathrm{Na}, \mathrm{Cu}, \mathrm{Ni}, \mathrm{Cl}$, and $\mathrm{S}$ ) were accumulated in this melt. The last drops of melt, left after the crystallization of ore minerals and carbonates, were enriched in $\mathrm{Cl}$ and $\mathrm{S}$, promoting the formation of chlorides and sulfates. Moreover, the presence of $\mathrm{H}_{2} \mathrm{O}$-bearing phases such as tetraferriphlogopite and mineral of the humite group in olivine-hosted inclusions suggests that evolved kimberlitic melt may be slightly rich in. It can not be also ruled out that the kimberlitic melt was able to assimilate some evaporites from the country sedimentary rocks that served as an additional source of $\mathrm{Na}, \mathrm{K}, \mathrm{S}$, and $\mathrm{Cl}$.

The study of olivine-hosted inclusions has shown that $\mathrm{Ca}-\mathrm{Mg}$-Fe-carbonates, $\mathrm{Na}-\mathrm{Ca}$-carbonates, and djerfisherite were formed in kimberlites of the Udachnaya-Eastern pipe at the late magmatic stage. In the process of crystallization, the kimberlitic melt was evolved toward carbonatitic compositions. Thermobarogeochemical investigations of the Palabora alkaline-carbonatite complex (South Africa) have shown that the melt inclusions in minerals from this complex are characterized by approximately the same assemblage of crystalline phases like the secondary inclusions in olivine from kimberlites of the Udachnaya-Eastern Pipe (Aldous, 1986; Solovova et al., 1998).

\section{ACKNOWLEDGMENTS}

This work was supported by the Russian Foundation for Basic Research (project nos. 02-05-64620 and 00-1598541) and by the United Institute of Geology, Geophysics and Mineralogy, Siberian Division, Russian Academy of Sciences (young scientist project no. 1762). 


\section{REFERENCES}

Aldous, R., 1986. Copper-rich fluid inclusions in pyroxenes from the Guide Copper Mine, a satellite intrusion of the Palabora Igneous Complex, South Africa. Econ. Geol., 81, 143-155.

Bulanova, G.P., Spetsius, Z.V., Leskova, N.V., 1990. Sulfides in diamonds and xenoliths from kimberlitic pipes of Yakutia. Publ. H. Nauka, Novosibirsk, 120 pp. (in Russian).

Clarke, D.B., Mitchell, R.H., Chapman, C.A.T., MacKay, R.M., 1994. Occurrence and origin of djerfisherite from the Elwin Bay kimberlite, Somerset Island, Northwest Territories. Can. Mineral., 32, 815-823.

Clarke, D.B., Pe, G.G., MacKay, R.M., Gill, K.R., O'Hara, M.J., Gard, J.A., 1977. A new potassium - iron nickel sulfide from a nodule in kimberlite. Earth Planet. Sci. Lett., 35, 421-428.

Dobrovol'skaya, M.G., Tsepin, A.I., Ilupin, I.P., Ponomarenko, A.I., 1975. Djerfisherite from the Yakutian kimberlites. In: Tamarinov, P.M. (Ed.), Mineraly i Paragenezisy Mineralov Endogennykh Mestorozhdenii. Publ. H. Nauka, Leningrad, 3-11 (in Russian).

Egorov, K.N., Ushchapovskaya, Z.F., Kashaev, A.A., Bogdanov, G.V., Sizykh, Yu.I., 1988. Zemkorite, a new carbonate from kimberlites of Yakutia. Dokl. Akad. Nauk USSR, 301, 188-193 (in Russian).

Kamenetskaya, M.B., Sobolev, A.V., Sobolev, N.V., and Pokhilenko, N.P., 2002. Kimberlite parental melts: new insights from inclusions in olivine. Geochim. Cosnochim. Acta, 66 (S1), p. A380, Abstract Volume of the XII Goldschmidt Conf., Davos, 2002.

Khomyakov, A.P., Cherepivskaya, G.E., Timchenko, A.D., 1980. Shortite $\mathrm{Na}_{2} \mathrm{Ca}_{2}\left(\mathrm{CO}_{3}\right)_{3}$, first discoveries in USSR. Mineral. Zh., 2 (2), 85-89 (in Russian).

Marshintsev, V.K., Migalkin, K.N., Nikolaev, N.S., Barashkov, Yu.P., 1976. Unaltered kimberlite from the Udachnaya-Eastern pipe. Dokl. Akad. Nauk USSR, 231, 961-964 (in Russian).

Mazurin, O.V., Strel'tsina, M.V., Shvaiko-Shvatskovskaya, T.N., 1973-1981. Properties of glasses and glassforming melts: a handbook), Leningrad: Nauka (in Russian).

Pokhilenko, N.P., Usova, L.V., 1978. Secondary melt inclusions in olivines from the Udachnaya kimberlite pipe (Yakutia). Abstracts of IV Conf. on Thermobarogeochemistry, Vladivostok, USSR, pp. 66-67 (in Russian).

Popivnyak, I.V., Laz'ko E.E, 1979. Inclusions of solidified melts in minerals of kimberlitic rocks from Western Yakutia. Dokl. Akad. Nauk USSR, 244, 194-197 (in Russian).

Sobolev, A.V., Sobolev, N.V., Smith, C.B., Dubessy, J., 1989. Fluid and melt compositions in lamproites and kimberlites based on the study of inclusions in olivine. Proc. IV Int. Kimb. Symp.: Kimberlite and Related Rocks, Perth: GSA Spec. Publ., no. 14, vol. 1, pp. 220-240.
Sobolev, N.V., Khar'kiv, A.D., Pokhilenko, N.V., 1986. Kimberlites, lamproites and problem of composition of upper mantle. Soviet Geol. Geophys., 27 (7), 18-28 (in Russian)

Sobolev, N.V., Yefimova, E.S., 1997. Syngenetic mica inclusions in diamonds: evidence for volatiles significance in deep lithospheric mantle. Abstract Vol. Geol. Soc. Am. Ann. Meeting, Salt Lake City, 29, p. A191.

Solovova, I.P., Ryabchikov, I.D., Kogarko, L.N., Kononkova, N.N., 1998. Inclusions in minerals of the Palabora carbonatite complex, South Africa. Geokhimiya, no. 5, 435-447 (in Russian).

Zedgenizov, D.A., Logvinova, A.M., Shatskii, V.S., Sobolev, N.V., 1998. Inclusions in microdiamonds from some kimberlite diatremes of Yakutia. Dokl. Acad. Sci., Earth Sci. Sect., 359, 204-208.

Contact: AV Golovin, Institute of Mineralogy and Petrography, Koptyuga prospect 3, 630090 Novosibirsk, Russia, E-mail: avg@uiggm.nsc.ru 